\title{
Article/Artigo
}

\section{Level of behavior and knowledge concerning human papillomavirus among university students of a nursing college}

\author{
Nível do comportamento e conhecimento sobre o papilomavírus humano entre universitários \\ do curso de enfermagem
}

\section{Camila Aparecida Cirilo ${ }^{1}$, Adriana Sierra Assêncio Almeida Barbosa ${ }^{2}$ and Érika Zambrano ${ }^{3}$}

\begin{abstract}
Introduction: Human pappilomavirus is one of the most common sexually transmitted diseases, and persistent HPV infection is considered the most important cause of cervical cancer. It is detected in more than $98 \%$ of this type of cancer. This study aimed to determine the level of knowledge concerning human papillomavirus among nursing college students of a private educational institution located in the City of Bauru, SP, and correlate their knowledge according to the course year. Methods: A descriptive study with a quantitative approach, performed with a questionnaire that permitted the quantification of data and opinions, thus guaranteeing the precision of the results without distortions in analysis or interpretation. The survey was applied to randomly selected $1^{\text {st }}, 2^{\text {nd }}, 3^{\text {rd }}$, and $4^{\text {th }}$-year nursing college students. Twenty students from each level were selected during August 2009, totaling 80 students of both genders. Results: Observation revealed that $4^{\text {th }}$-year students had greater knowledge than $1^{\text {st }}$-year students, reflecting the greater period of study, the lack of knowledge of $1^{\text {st }}$-year students was due to the low level of information acquired before entering college. Conclusions: The need for complementary studies which determine the profile and knowledge of a larger number of teenagers in relation to HPV was established. The need for educational programs that can overcome this lack of information is undeniable, especially those aimed at making adolescents less susceptible to HPV and other STDs.
\end{abstract}

Key-words: Nursing students. HPV. Prevention and diagnosis.

\section{RESUMO}

Introdução: $\mathrm{O}$ papilomavírus humano é uma das doenças sexualmente transmissível mais comum e a infecção persistente pelo HPV é considerada como a mais importante causa de câncer de colo de útero e chega a ser encontrado em mais de $98 \%$ deste tipo de câncer. $\mathrm{O}$ objetivo deste estudo foi determinar o nível de conhecimento sobre o HPV e correlacionar o ano em que está matriculado com os dados obtidos, entre estudantes do curso de enfermagem de uma instituição educacional privada localizada na Cidade de Bauru, SP. Métodos: Estudo descritivo com abordagem quantitativa, realizado através de questionário que permitiu quantificar dado e opiniões garantindo a precisão dos resultados sem distorções de análise e interpretações, a pesquisa foi aplicada nos estudantes do $1^{\circ} .2^{\circ}, 3^{\circ}$ e $4^{\circ}$ ano do curso de Enfermagem sendo selecionados de forma aleatória 20 alunos de cada ano, totalizando 80 estudantes de ambos os sexos, no mês de agosto de 2009. Resultados: Observou-se que os alunos do $4^{\circ}$ ano apresentaram um conhecimento superior aos alunos do $1^{\circ}$ ano, tendo em vista o maior tempo de estudo, a falta de conhecimento dos alunos do $1^{\circ}$ ano, deve-se ao baixo nível de informação adquirida antes de entra na faculdade. Conclusões: Faz-se necessária realização de estudos adicionais que demonstrem qual perfil e conhecimento de um maior número de adolescentes com relação ao HPV. É indiscutível a necessidade de campanhas educativas que possam suprimir a falta de informação, tornando os jovens menos susceptíveis à infecção pelo HPV e outras DST.

Palavras-chaves: Estudantes de enfermagem. HPV. Prevenção e diagnóstico.

1. Vaccination Clinic Biolab Laboratory, Bauru, SP, Brazil. 2. Technical Biology Team, Lauro de Souza Lima Institute, Bauru, SP, Brazil. 3. Bauru Anhanguera Educational School, Bauru, SP, Brazil.

Address to: Dra Camila Aparecida Cirilo. Vacination Clinic Biolab Laboratory. Rua Gustavo Maciel Dias 1640, 17015-321 Bauru, SP, Brasil.

Phone: 55 143214-3432

e-mail: camilinhacac@hotmail.com

Received in 01/04/2010

Accepted in 28/04/2010

\section{INTRODUCTION}

Human papillomavirus (HPV) belongs to the family Papovaviridae and is formed by doublestranded, nonenveloped, circular DNA, with approximately 7,200 to 8,000 base pairs $^{1}$. It can lead to a variety of benign, premalignant and malignant lesions in the mucosa and cutaneous tissues ${ }^{1}$. Genital HPV infection is one of the most frequent sexually transmitted diseases ${ }^{2,3}$. In a high prevalence context, infectivity and diagnosis are made by examining the clinical, subclinical and asymptomatic lesions; the dissemination of HPV is universal among the sexually active population, where men are an important means for the proliferation of the virus ${ }^{1-4}$.

It is estimated that 15 to $40 \%$ of the world's population is contaminated with $\mathrm{HPV}^{5,6}$; furthermore, more than 500,000 new cases occur worldwide every year. Among these, $70 \%$ occur in developing countries and $90 \%$ are associated with spinocellular cancer of the anal canal ${ }^{7,8}$.

Persistent HPV infection is considered the most important cause of cancer of the uterine cervix and its participation in development of other genital neoplasias has been suggested, including the vulva, penis, anus and oral cavity. It is believed that HPV is involved in 10 to $15 \%$ of all human neoplasias ${ }^{1,9-13}$.

Considering the dimensions of the problem, it is necessary to efficiently contain the outbreak of HPV infection and its sequelae and immunization offers one such opportunity ${ }^{5,13-19}$. Nowadays, the available vaccines against HPV prevent the types of HVP responsible for $90 \%$ of the warts, $70 \%$ of the high-grade carcinomas and precancerous lesions and 35 to $50 \%$ of the low-grade vulvar lesions ${ }^{3,5,19}$.

Vaccination has proven to be more effective when administrated before the onset of sexual activity by the individual and vaccination campaigns are now targeted at teenagers and pre-teenagers. We hope that with wide-scale usage of vaccines, $70 \%$ of cervical cancers can be prevented, as well as the same proportion of other anogenital diseases associated with HPV infection. However, vaccination against 
$\mathrm{HPV}$ is one of the hopes for the future and the vaccination program proposed by the Brazilian government, when it is available, shall be clear, precise and with an educational message not only for those who remain uninformed, but also for health professionals ${ }^{3,5,18}$.

HPV remains an infection that is rarely discussed within society. A recent study demonstrated the low level of knowledge and wide spread misconceptions regarding STDs, especially HPV. It also revealed that the level of knowledge is still far below that required ${ }^{20}$.

Given these facts, we considered it important to evaluate the level of knowledge concerning HPV among nursing students of a private educational institution, located in the City of Bauru, SP, Brazil, and correlate the data obtained through the survey with the year in which the students were enrolled.

\section{METHODS}

This is a descriptive study with a quantitative approach, which was conducted in a private educational institution in the City of Bauru, State of Sao Paulo, Brazil. This institution offers a nursing course, where the survey was conducted. The survey was applied to randomly selected $1^{\text {st }}, 2^{\text {nd }}, 3^{\text {rd }}$, and $4^{\text {th }}$-year students, 20 students from each year, of both genders, during August 2009. Criteria for exclusion included those under 18 years-old, those who did not agree to participate in the survey, those who were not enrolled in the institution and those who did not fill out the entire survey.

\section{Statistical analysis}

The data was analyzed descriptively. The percentual data analysis technique was used and the results were presented as the mean \pm SD. The graphs were structured using the Microsoft Excel program and the tables were structured using the Microsoft Word program.

\section{Ethical}

The research project was submitted to and approved by the Anhanguera College Research Ethics Committee. All the participants of the survey signed a term of free, informed consent regarding their participation in the research.

\section{RESULTS}

The participants of this research were basically composed of female students, who represented $90 \%$ ( 72 students) of the total, with men consisting of $10 \%$ ( 8 students). The students' mean age was 27.8 years-old.

With the intention of evaluating the level of knowledge of the students concerning HPV, some questions were asked regarding the definition, consequences, prevention, susceptibility, symptoms and diagnosis of HPV.

Figure 1 presents the students knowledge concerning HPV, where $86 \%$ of the interviewees stated knowledge concerning HPV, while $11 \%$ had previously heard about HPV and only $3 \%$ have never heard about HPV.

The percentage of students with knowledge of HPV was analyzed according to enrollment year: among $2^{\text {nd }}$ and $3^{\text {rd }}$-year students, $100 \%$ of the interviewees stated knowledge of HPV; among $4^{\text {th }}$-year students, $90 \%$ of the interviewees stated such knowledge; and among $1^{\text {st }}$-year students, it was $55 \%$.

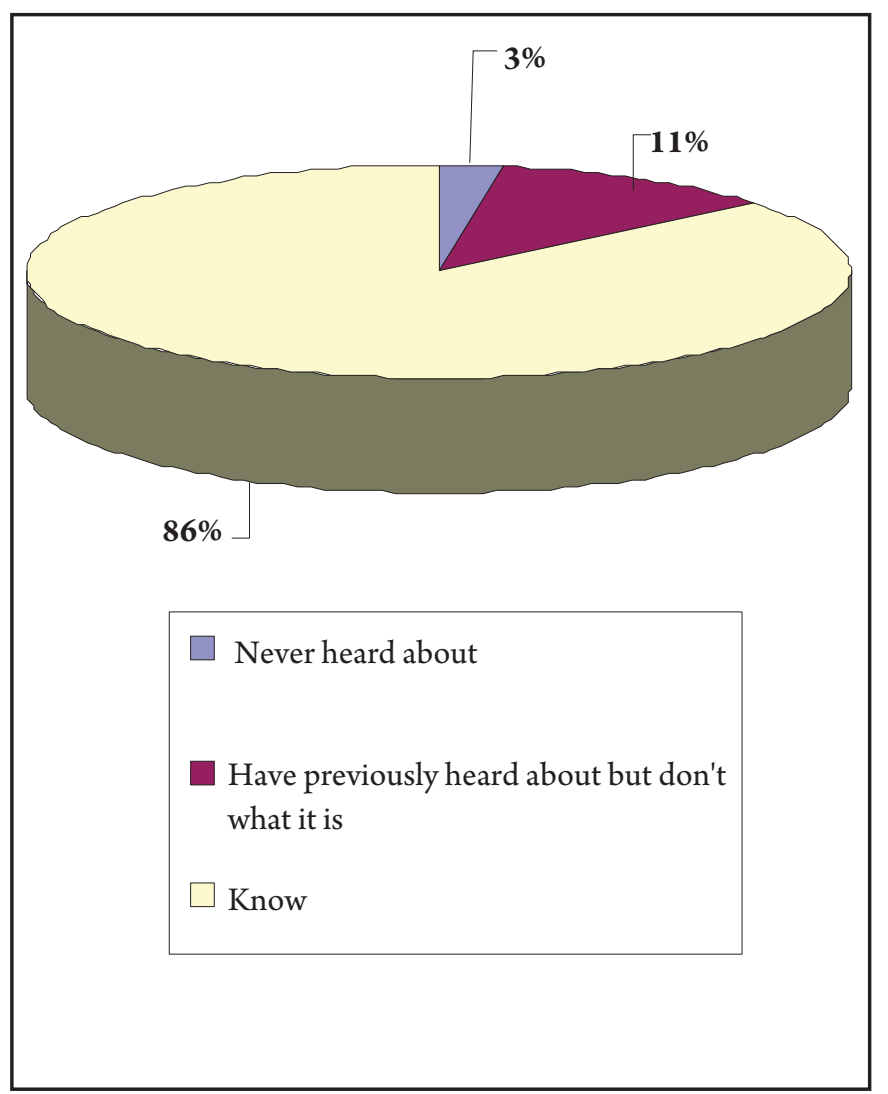

FIGURE 1 - General distribution of knowledge regarding human papilloma virus among the Nursing College students.

Analysis of the results for the question regarding the route of HPV contamination showed that $90 \%$ the students answered that it occurred through sexual intercourse, $6 \%$ answered through blood transfusion, $2 \%$ answered others and $2 \%$ did not have an opinion. Moreover, analysis revealed that sexual intercourse was the response of $100 \%$ of the $2^{\text {nd }}, 3^{\text {rd }}$, and $4^{\text {th }}$-year students, while only $78 \%$ of $1^{\text {st }}$-year students responded correctly.

The question regarding situations which could increase the chances of contagious disease revealed that $34 \%$ answered sexual intercourse without a condom, $33 \%$ answered having multiple sex partners and $10 \%$ answered having sexual intercourse at a too young an age. This question permitted more than one answer. Analysis verified that, in relation to the susceptibility of contracting HPV, $37 \%$ of $2^{\text {nd }}$ - and $4^{\text {th }}$-year students considered having multiple sex partners the predominant risk factor, while $33 \%$ of $3^{\text {rd }}$-year students considered early sexual initiation and the lack of using a condom and $34 \%$ of $1^{\text {st }}$-year students considered the lack of using a condom as the predominant risks.

In relation to the question regarding predominance of a sex, $60 \%$ of the students considered that both sexes are targeted in the same proportion, $36 \%$ stated that only or mainly women are capable of acquiring HPV, $2 \%$ answered that only or mainly men are capable of acquiring HPV and $2 \%$ had no opinion.

In relation to knowledge regarding the frequency of HPV symptoms, $72 \%$ stated that HPV infection is often symptomatic, while $14 \%$ stated that it is always symptomatic, $9 \%$ stated that it is never symptomatic and 5\% had no opinion. Further analysis revealed that $55 \%$ of $1^{\text {st }}$-year students, $85 \%$ of $2^{\text {nd }}$-year and $75 \%$ of $3^{\text {rd }}$ - and $4^{\text {th }}$-year students stated that the HPV infection is sometimes symptomatic. 
Figure 2 presents student knowledge concerning the long term effects of HPV, where $86 \%$ believe that HPV can cause cervical cancer. One interesting piece of information was that $10 \%$ of the students stated that HPV does not have any long term effect.

In relation to the year of enrollment, $80 \%$ of $1^{\text {st }}$-year students, $77 \%$ of $2^{\text {nd }}$-year, $90 \%$ of $3^{\text {rd }}$-year and $95 \%$ of $4^{\text {th }}$-year students believe that HPV can cause cervical cancer.

Figure 3 presents the students' level of knowledge regarding prevention, where $56 \%$ stated that the usage of condoms can prevent HPV, another $36 \%$ of the interviewees believe that vaccination is the main preventive agent, while $5 \%$ of the interviewees believed in other prevention methods, such as the Papanicolaou exam coupled with avoiding more than one sex partner.

The distribution per enrollment year revealed that $68 \%$ of $1^{\text {st }}$-year students, $56 \%$ of $2^{\text {nd }}$-year, $48 \%$ of $3^{\text {rd }}$-year and $61 \%$ of $4^{\text {th }}$-year students mentioned condoms as a preventive agent. Another $24 \%$ of $1^{\text {st }}$-year students, $41 \%$ of $2^{\text {nd }}$ year, $41 \%$ of $3^{\text {rd }}$-year and $36 \%$ of $4^{\text {th }}$-year students mentioned vaccination as the main preventive agent.

In relation to HPV diagnosis, $48 \%$ of the interviewees stated knowledge of the diagnosis, $44 \%$ had previously heard about it, but could not determine diagnosis, while $8 \%$ had never heard about it. Among those who stated they had some knowledge of HPV diagnosis, $56 \%$ cited the Papanicolaou exam as the main form of diagnosis.

Figure 4 shows that $11 \%$ of $1^{\text {st }}$-year students, $65 \%$ of $2^{\text {nd }}$-year, $52 \%$ of $3^{\text {rd }}$-year and $65 \%$ of $4^{\text {th }}$-year students claimed to know the diagnosis. Those who had previously heard of, but could not describe it included $73 \%$ of $1^{\text {st }}$-year students, $20 \%$ of $2^{\text {nd }}$-year, $48 \%$ of $3^{\text {rd }}$-year and $35 \%$ of $4^{\text {th }}$-year students.

The question regarding predisposition for cervical cancer due to HPV revealed that $92 \%$ of the students knew that HPV can cause cervical cancer, while only $8 \%$ did not know; $85 \%$ of $1^{\text {st }}$-year students,

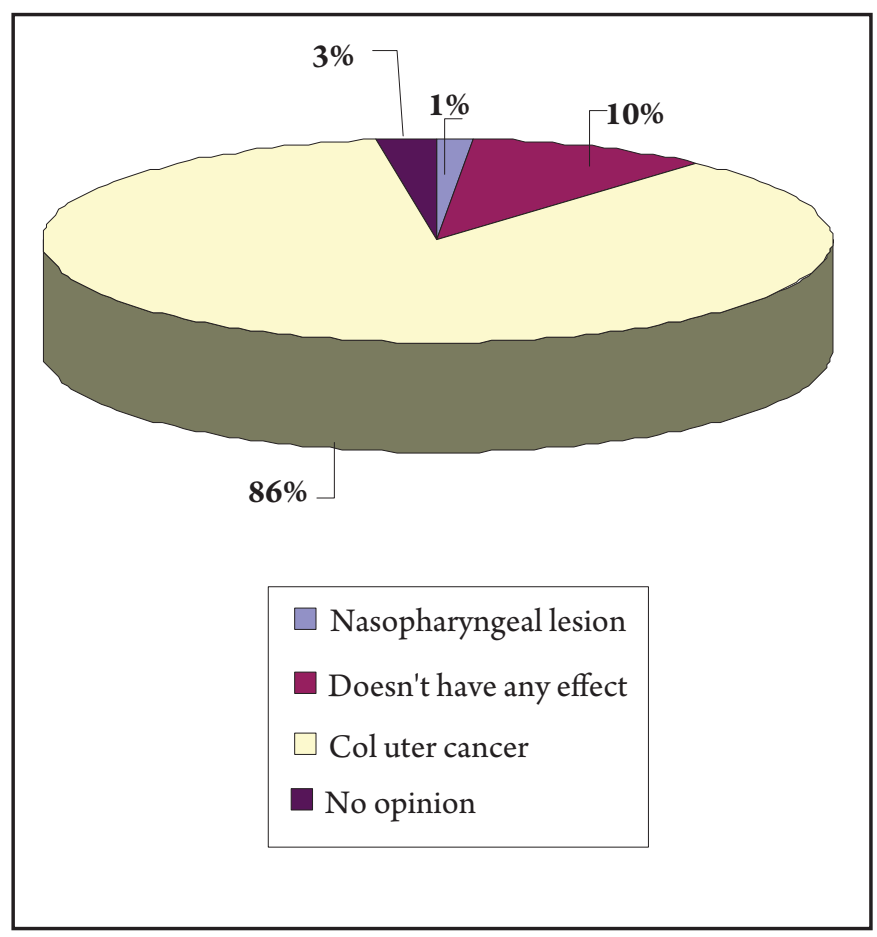

FIGURE 2 - General distribution of knowledge concenring the long term effects of human papilloma virus among the Nursing College students.
$95 \%$ of $2^{\text {nd }}$-year, $100 \%$ of $3^{\text {rd }}$-year and $90 \%$ of $4^{\text {th }}$-year answered that the HPV can cause cancer of the uterine cervix.

In relation to the vaccination as a form of HPV prevention, $51 \%$ stated they knew of the existence of the vaccine, another $27 \%$ of the interviewees stated that they had previously heard about it, but they did not know which vaccine was the correct one, while $22 \%$ had never heard about a vaccine. Figure 5 reveals that $10 \%$ of $1^{\text {st }}$-year students, $69 \%$ of $2^{\text {nd }}$-year, $70 \%$ of $3^{\text {rd }}$-year and $60 \%$ of $4^{\text {th }}$-year students stated that they already knew about the vaccine as a preventive agent.

The interviewees were questioned regarding the number of partners they had had since the onset of their sex lives and $65 \%$ stated they had had between 1 and 3 partners since their sexual initiation, $16 \%$ between 4 and $6,11 \%$ more than 6 partners and $8 \%$ stated they were virgins.

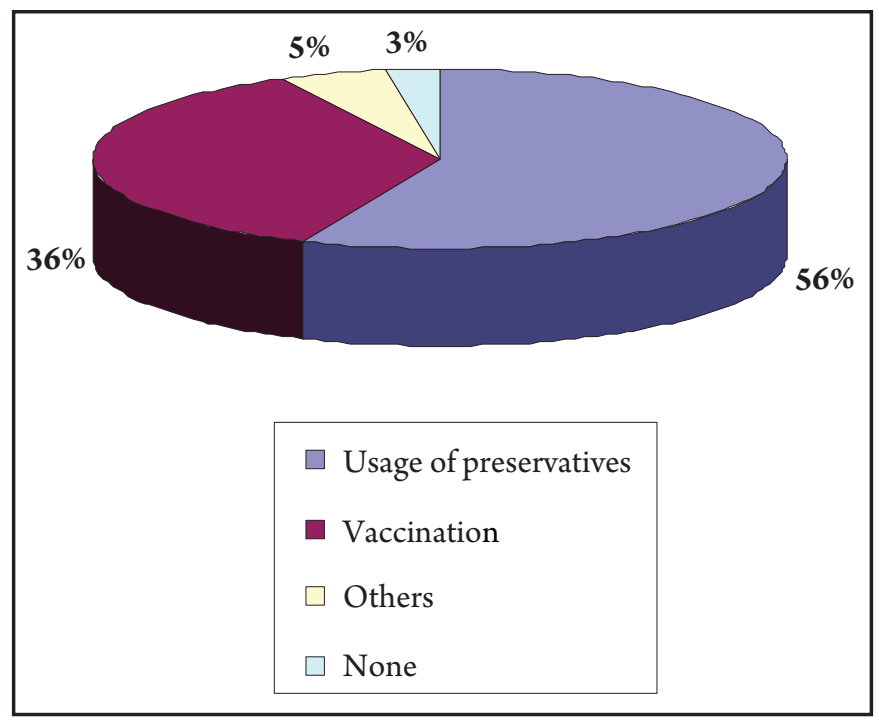

FIGURE 3 - General distribution of knowledge concering preventive methods for human papilloma virus among the Nursing College students.

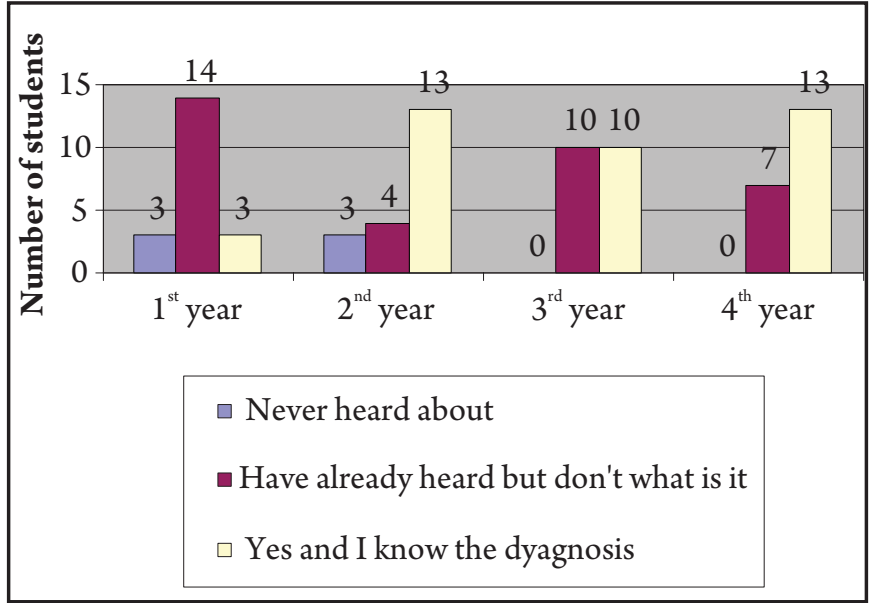

FIGURE 4 - Distribution of knowledge concering the diagnosis of human papilloma virus among the Nursing College students, according to enrollment year. 


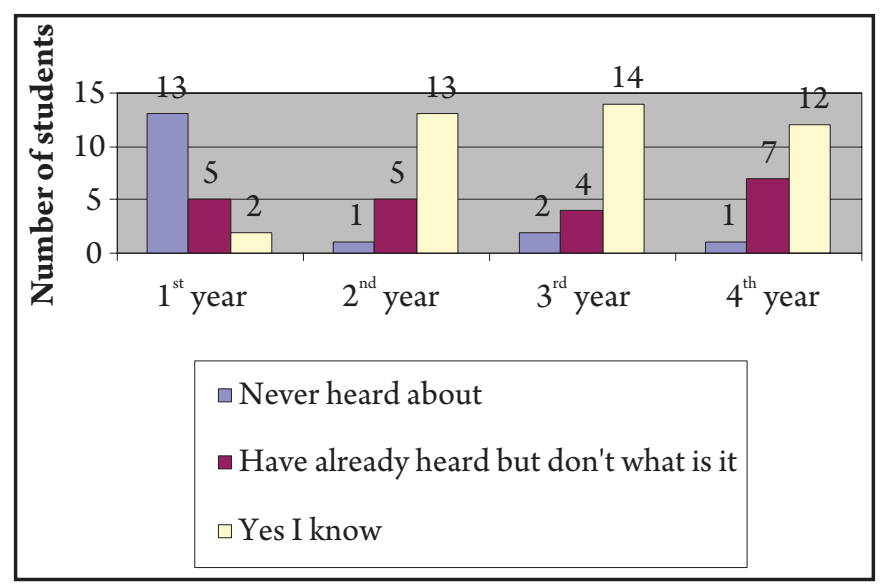

FIGURE 5 - Distribution of knowledge concerning the vaccine as a preventing agent against infection by human papilloma virus (HPV) among the Nursing College students, according to enrollment year.

\section{DISCUSSION}

The majority of participants in this study (90\%) were women, against $10 \%$ of men. This can be explained by the fact that the participants were all from a nursing college, a course in which women are predominant, according to Wetterich et $\mathrm{al}^{21}$.

This fact is related to the prejudicial image of this profession, prejudice which historically defines Nursing as being a women's profession. According to the authors, the interest among men for this profession apparently shows that conceptions concerning Nursing are going through a series of transformations, leaving behind the idea of a predominantly female profession, although they are still the majority in this area.

The ages of the interviewees ranged from 18 to 51 years-old, with a mean of 27.8 years-old. Since they are students from a private institution and attend the night course, the average age results differ from the data of Peres et $\mathrm{al}^{22}$, who highlighted that the majority of university students in Brazil who enroll in higher education are, on average, 20 years-old.

In relation to the level of knowledge of the students concerning HPV, a good overall average of $86 \%$ of the students was obtained; however, only $55 \%$ of the students in their first year of college stated that they were aware of HPV, 35\% said they had heard about it, but did not know what it was, while $10 \%$ had never heard about it. The same results were observed concerning the level of knowledge of the contagious characteristics of HPV. $100 \%$ of the students enrolled in the college in the $2^{\text {nd }}, 3^{\text {rd }}$ and $4^{\text {th }}$ years knew that this disease is acquired through sexual intercourse, against $78 \%$ of $1^{\text {st }}$-year students, leading to the conclusion that part of the students have some knowledge regarding HPV, that this knowledge was probably acquired through other means before college life and that their knowledge tends to increase during the nursing course. Similar data was also verified by Conti et $\mathrm{al}^{20}$.

The answers to the question concerning the situations which increase the risk of contracting HPV and which permitted more than one answer, showed a high level of knowledge among the students,

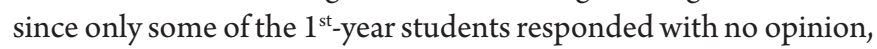
while the other students indicated more than one situation which increases the risk, a fact also considered by Sousa et $\mathrm{al}^{23}$.
Among the interviewees, $60 \%$ believed that both sexes are targeted by HPV in the same proportion. Sousa et $\mathrm{al}^{23}$ and Conti et $\mathrm{al}^{20}$ reported similar data in their research.

In relation to the symptoms, Conti et $\mathrm{a}^{20}$ showed that the majority of the students did not know much about the subject. In this study, $72 \%$ stated that the HPV infection is sometimes symptomatic and $85 \%$ believe that the HPV can cause cancer of the uterine cervix.

According to Conti et $\mathrm{al}^{20}$, in their study the students were not aware of the real function of the preventive exam and further reported that it is fundamental that health institutions alert the population concerning the importance of the preventive exam, because the exam permits a reduction of up to $70 \%$ in mortality due to cervical cancer among the risk population. In this study, $57 \%$ stated that the use of condoms can prevent HPV, $37 \%$ of the interviewees believed that vaccination is the main preventive agent, while $4 \%$ believed in other preventive methods, for example, the Papanicolaou exam and not having multiple sex partners.

Thus, although the current prophylactic vaccines protect noninfected women, those infected prior to vaccination still require diagnosis and treatment for preneoplastic lesions. Even if it were extremely efficient and involved a great coverage rate, a large scale vaccination program against HPV would take years to show noticeable epidemiological effects. It is important to highlight that vaccination does not eliminate the necessity for routine examinations for cervical cancer ${ }^{3,5,18}$.

In relation to diagnosis, $48 \%$ of the interviewees stated that they knew the diagnosis, $44 \%$ had previously heard about it but did not know what it was, while $8 \%$ had never heard about it. This data corroborates findings from other studies ${ }^{20-23}$.

Regarding the onset of their sex lives and the number of partners, the majority of the students, $92 \%$, had already initiated their sex lives and $65 \%$ had already had an average 1 to 3 sex partners. This group can be classified as a sexual active population, which justifies the interest in studies on the level of knowledge concerning HPV among nursing students $\mathrm{s}^{20-23}$.

The present study was performed on students of the nursing college and revealed a lack of information and misconceptions among $1^{\text {st }}$-year students regarding HPV. The level of information among these students was less than desirable. This fact is due to the low level of information acquired prior to their enrollment in college and that in their first year they still have not studied STDs or HPV.

In this very complex context, nurses are valuable members of the health staff who have a fundamental role in the educational process for the health of the population; however, for them to participate in the educational process, it is crucial that sex has been widely discussed using all means of communication, in order to enhance the level of knowledge of these professionals.

The goals proposed for this study were fulfilled, since, in general, analysis of the knowledge of HPV among the students was adequate; moreover, the $4^{\text {th }}$-year students showed a greater level of knowledge in relation to the $1^{\text {st }}$-year students due to the longer period of study.

The need for further studies which determine the profile and knowledge of a larger number of teenagers in relation to HPV was clearly established. The need to implement educational programs that can provide the information they lack is also undeniable, so that adolescents become less susceptible to HPV infection and other sexually transmitted diseases. 


\section{ACKNOWLEDGMENTS}

The authors would like to thank to Bauru Anhanguera Educational School, Bauru, Sao Paulo State, Brazil.

\section{CONFLICT OF INTEREST}

The authors declare that there is no conflict of interest.

\section{REFERENCES}

1. Xavier SD, B Filho I, Carvalho JM, Framil VMS, Castro TMPPG. Freqüência de aparecimento de Papilomavírus Humano (HPV) na mucosa oral de homens com HPV anagenital confirmado por biologia molecular. Arq Int Otorrinolaringol 2007; 11:36-44.

2. Nonnenmacher B, Breitenbach V, Villa LL, Prolla JC, Bozzetti MC. Identificação do papilomavírus humano por biologia molecular em mulheres assintomáticas. Rev Saude Publica 2002; 36:95-100.

3. Derchain SFM, Sarian LOZ. Vacinas profiláticas para o HPV. Rev Bras Ginecol Obstet 2007; 29:281-284.

4. Teixeira JC, Santos CC, Derchain SFM, Zeferino LC. Lesões induzidas por papilomavírus humano em parceiros de mulheres com neoplasia intra-epitelial do trato genital inferior. Rev Bras Ginecol Obstet 1999; 21:431-437.

5. Nadal LRM, Nadal SR. Indicações da vacina contra o Papilomavírus Humano. Rev Bras Coloproct 2008; 28:124-126.

6. Rama CH, Roteli-Martins CM, Derchain SFM, Oliveira EZ, Aldrigho JM, Marian CN. Detecção sorológica de anti HPV 16 e 18 e sua associação com achados do Papanicolaou em adolescentes e mulheres jovens. Rev Assoc Med Bras 2006; 52:43-47.

7. Nadal SR, Manzione CR. Uso do colposcópio para avaliar a região perianal e o canal anal-padronização técnica da nomenclatura e indicações. Rev Bras Coloproct 2004; 24:379-381.

8. Queiroz DT, Pessoa SMF, Sousa RA. Infecção pelo Papilomavírus (HPV) incertezas e desafios. Acta Paul Enferm 2005; 18:190-196.

9. Rama CH, Roteli-Martins CM, Derchain SFM, Longatto-Filho A, Gontijo RC, Sarian LOZ, et al. Prevalence of genital HPV infection among women screened for cervical cancer. Rev Saude Publica 2008; 42:123-130.

10. Teixeira JC, Derchain SFM, Teixeira LC, Santos CC, Panetta K, Zeferino LC. Male Sexual Partner Evaluation and Relapse Risk in Women Treated for Genital Human Papillomavirus (HPV) Lesions. Rev Bras Ginecol Obstet $2002 ; 24: 315-320$

11. Murta EFC, Souza MAH, Adad SJ, Araújo Júnior E. Infecção pelo Papilomavírus Humano em Adolescentes: relação com o método anticoncepcional, gravidez, fumo e achados citológicos. Rev Bras Ginecol Obstet 2001; 23:217-221.

12. Magi JC, Brito SEM, Grecco ETO, Pereira SMM, Galdino JS. Prevalência de papilomavirus humano (HPV) anal, genital e oral, em ambulatório geral de coloproctologia. Rev Bras Coloproct 2006; 26:233-238.

13. Pinto AP, Túlio S, Cruz OR. Co-fatores do HPV na oncogênese cervical. Rev Assoc Med Bras 2002; 48:73-78.

14. Cerqueira DM, Moraes DS, Milanezi N, Camara GNL, Amaral FA, Oyama CNR, et al. Caracterização molecular do Papilomavírus Humano em mulheres infectadas com o vírus da imunodeficiência humana do tipo 1 no Distrito Federal e Entorno. Com Ciencias Saude 2007; 18:267-278.

15. Uchimura NS, Ribalta JCL, Focchi J, Baracat EC, Uchimura TT. Influência do uso de anticoncepcionais hormonais orais sobre o número de células de Langerhans em mulheres com captura hídrica negativa para Papilomavírus humano. Rev Bras Ginecol Obstet 2005; 27:726-730.

16. Magi JC, Rodrigues MRS, Guerra GMLS, Costa MC, Costa ACL, Villa LL, et al. Resultados do exame anátomo-patológico e "Polymerase Chain Reaction (PCR)" na forma clínica e subclínica da infecção anal pelo Papilomavírus Humano (HPV) - Estudo em quatro grupos de pacientes. Rev Bras Coloproct 2006; 26:406-413.
17. Roteli-Martins CM, Longatto Filho A, Hammes LS, Derchain SFM, Naud P, Matos JC, et al. Associação entre a idade ao início da atividade sexual e subseqüente infecção por Papilomavírus Humano: resultados de um programa de rastreamento brasileiro. Rev Bras Ginecol Obstet 2007; 29:580-587.

18. Nadal SR, Manzione CR. Vacinas contra o Papilomavirus Humano. Rev Bras Coloproct 2006; 26:337-340.

19. Noronha V, Mello W, Villa L, Brito A, Macêdo R, Bisi F. Papilomavírus humano associado a lesões de cérvice uterina. Rev Soc Bras Med Trop 1999; 32:235-240.

20. Conti FS, Bortolin S, Kulkamp IC. Educação e Promoção à Saúde: Comportamento e conhecimento de Adolescentes de Colégio Público e Particular em Relação ao Papilomavírus Humano. DST - J Bras Doenças Sex Transm 2006; 18:30-35.

21. Wetterich NC, Melo MRAC. Perfil sociodemográfico do aluno do curso de graduação em enfermagem. Rev Latino-Am Enf 2007; 15:404-410.

22. Peres RS, Santos MA, Coelho HMB. Perfil da clientela de um programa de pronto-atendimento psicológico a estudantes universitários. Psicol em Estudo 2004; 9:47-54

23. Sousa LB, Pinheiro AKB, Barroso MGT. Ser mulher portadora do HPV uma abordagem cultural. Rev Esc Enferm USP 2008; 42:737-743. 